\title{
Hepatitis B Vaccine-Associated Atypical Hemolytic Uremic Syndrome
}

\section{Hepatit B Aşısı ile İlişkili Atipik Hemolitik Üremik Sendrom}

\author{
Zekai Avcı1, Cengiz Bayram², Barıș Malbora 3 \\ ${ }_{1}^{1}$ Ankara Children's Hematology and Oncology Research Hospital, Department of Hematology, Ankara, Turkey \\ 2 Ankara Pediatric and Pediatric Hematology Oncology Training and Research Hospital, Department of Pediatric Hematology, Ankara, Turkey \\ ${ }^{3}$ Dr. Sami Ulus Research and Training Hospital of Women's and Children's Health and Diseases, Ankara, Turkey
}

\section{To the Editor,}

Hemolytic uremic syndrome (HUS) is one of the common causes of acute renal failure in children and is characterized by microangiopathic hemolytic anemia and thrombocytopenia. About $5 \%$ to $10 \%$ of all HUS cases in children are nondiarrheal HUS (atypical HUS) [1,2]. Many triggering causes of atypical HUS, such as non-enteric infections, viruses, drugs, systemic diseases, glomerulopathies, malignancies, transplantations, and pregnancy, have been identified $[1,2,3,4]$. Here we report a patient who developed atypical HUS after a hepatitis B vaccination.

A 55-day-old female infant was admitted to our hospital with sudden onset of jaundice and pallor 1 day after the second dose of recombinant hepatitis $\mathrm{B}$ vaccine injection (containing $10 \mu \mathrm{g} \mathrm{HBsAg} / 0.5 \mathrm{~mL}$ and $0.475 \mathrm{mg}$ aluminum hydroxide $/ 0.5 \mathrm{~mL}$ ). There was no history of fever, diarrhea, or cough. The first dose of hepatitis B vaccine was administered at birth. She had no health problems in the neonatal period and was solely breastfed. The family history was non-contributory.

On physical examination, the patient was in poor general condition and hypoactive with pale and icteric skin. Body temperature was $37^{\circ} \mathrm{C}$, pulse rate was $140 / \mathrm{min}$, respiratory rate was $48 / \mathrm{min}$, and blood pressure was $70 / 40 \mathrm{mmHg}$. There was no hepatosplenomegaly. Laboratory examination revealed a hemoglobin level of $51 \mathrm{~g} / \mathrm{L}$, leukocyte count of
10x109/L, platelet count of 28x109/L, and reticulocyte level of $3.9 \%$. Anisocytosis, poikilocytosis, polychromasia, helmet cells, marked schistocytes, and rare platelets were observed in the peripheral blood smear, compatible with microangiopathic hemolytic anemia and thrombocytopenia. Direct and indirect Coombs test results were negative. Biochemical analyses were as follows: urea $88 \mathrm{mg} / \mathrm{dL}$ (normal range: 5-18), creatinine $1.1 \mathrm{mg} / \mathrm{dL}$ (normal: 0.20.4 ), total bilirubin $13.7 \mathrm{mg} / \mathrm{dL}$ (normal: $<1.2$ ), direct bilirubin $2.6 \mathrm{mg} / \mathrm{dL}$ (normal: $<0.2$ ), uric acid $8.1 \mathrm{mg} /$ dL (normal: 2.4-6.4), aspartate aminotransferase $96 \mathrm{U} / \mathrm{L}$ (normal: 15-55), lactic dehydrogenase $4641 \mathrm{U} / \mathrm{mL}$ (normal: 170-580), and the other serum biochemical tests within normal limits. Urine microscopy showed numerous red blood cells. Microscopic examination of stool was normal and occult blood test results were negative. Her stool culture and urine culture were also negative. Serum complement component 3 (C3) and C4 levels were $76.5 \mathrm{mg} / \mathrm{dL}$ (normal: 79-752) and $5.89 \mathrm{mg} / \mathrm{dL}$ (normal: 16-38), respectively. Prothrombin time, activated partial thromboplastin time, and fibrinogen level were within the normal ranges. Renal ultrasound showed increased echogenicity in both kidneys. As the patient had acute renal failure, thrombocytopenia, and microangiopathic hemolytic anemia, she was diagnosed with HUS. After transfusion of red blood cells, intravenous fluid therapy was initiated and intravenous furosemide was administered. Fresh frozen plasma infusion was also started.

Address for Correspondence: Barış MALBORA, M.D.,

Dr. Sami Ulus Research and Training Hospital of Women's and Children's Health and Diseases, Ankara, Turkey

Phone: +903123056000 E-mail: barismalbora@gmail.com

Received/Geliş tarihi : July 2, 2013

Accepted/Kabul tarihi : July 19, 2013 
On the third day of hospitalization, she had a seizure that was ended with a single dose of midazolam and did not recur again. Hemolysis and thrombocytopenia continued until day 8 of hospitalization and the patient required red blood cell transfusions 5 times during this period. Urea and creatinine levels progressively rose to $119 \mathrm{mg} / \mathrm{dL}$ and $2.2 \mathrm{mg} / \mathrm{dL}$, respectively. She had no oliguria. Hypertension was treated with nifedipine and enalapril. On day 9 of hospitalization, renal function, thrombocytopenia, and hemolysis began to improve, and plasma therapy was discontinued within the following 2 days. She no longer needed dialysis. The patient was discharged in good general condition on day 16 of hospitalization with improved complete blood count, biochemical tests, and complement levels. Factor $\mathrm{H}$ and factor I levels were normal when measured 3 months after hospital discharge. At 6 months of age, the patient's hepatitis $\mathrm{B}$ antibody titer was at the protective level, and thus the third dose of hepatitis B vaccine was not administered. The patient completed the immunization schedule except for the third dose of hepatitis B without further problems. She is currently 38 months old and has no problems.

Differentiation of HUS into typical HUS and atypical HUS may become confusing according to prodromal symptoms. Because infants below 6 months of age are generally breastfed (pre-weaning period), exposure to Escherichia coli O157:H7 is less likely in this age group and, therefore, other causes of HUS should be considered in patients under 6 months of age [4]. Our patient was a 55-day-old infant with no history of bloody diarrhea or other infection. Her stool and urine cultures were negative for Escherichia coli and Shigella. Her clinical presentation was consistent with the diagnosis of atypical HUS.

Our patient had clinical and laboratory findings of atypical HUS approximately $l$ day after hepatitis $B$ vaccine injection, and thus we suggest that the hepatitis B vaccine may play a triggering role for the onset of atypical HUS. Geerdink et al. [5] first reported a patient who developed atypical HUS a few days after a hepatitis B vaccination in their cohort study and they observed a relapse shortly after combined anti-diphtheria-pertussis-tetanus-polio vaccination in the same patient. To our knowledge, ours is the second case of atypical HUS associated with hepatitis B vaccination. In contrast to the first reported case, we did not observe a relapse with other vaccinations.

The triggering role of vaccination in the onset or relapse of atypical HUS has not been defined yet. We suggest that, compatible with the other adverse effects of vaccination, the immune-mediated activation of the complementary system triggers atypical HUS development. Therefore, recent history of vaccination should be examined, especially in patients without any other triggering conditions. Further reports are needed to confirm this hypothesis.

Key Words: Hemolytic uremic syndrome, Hepatitis B vaccine, Children

\section{Authors' Contributions}

All authors planned and performed the experiments and wrote the manuscript.

\section{Conflict of Interest Disclosure}

There is no potential conflict of interest to disclose.

\section{References}

1. Amirlak I, Amirlak B. Haemolytic uraemic syndrome: an overview. Nephrology (Carlton) 2006;11:213-218.

2. Scheiring J, Rosales A, Zimmerhackl LB. Clinical practice. Today's understanding of the haemolytic uraemic syndrome. Eur J Pediatr 2010;169:7-13

3. Westra D, Wetzels JF, Volokhina EB, van den Heuvel LP, van de Kar NC. A new era in the diagnosis and treatment of atypical haemolytic uraemic syndrome. Neth J Med 2012;70:121-129.

4. Ariceta G, Besbas N, Johnson S, Karpman D, Landau D, Licht C, Loirat C, Pecoraro C, Taylor CM, Van de Kar N, Vandewalle J, Zimmerhackl LB; European Paediatric Study Group for HUS. Guideline for the investigation and initial therapy of diarrhea-negative hemolytic uremic syndrome. Pediatr Nephrol 2009;24:687-696.

5. Geerdink LM, Westra D, van Wijk JA, Dorresteijn EM, Lilien MR, Davin JC, Kömhoff M, Van Hoeck K, van der Vlugt A, van den Heuvel LP, van de Kar NC. Atypical hemolytic uremic syndrome in children: complement mutations and clinical characteristics. 2012;27:1283-1291. 